\title{
Pollen analysis in honey samples from the two main producing regions in the Brazilian northeast
}

\author{
GENI DA S. SODRÉ ${ }^{1}$, LUÍS C. MARCHINI ${ }^{2}$, CARLOS A.L. DE CARVALHO ${ }^{1}$ \\ and AUGUSTA C. DE C.C. MORETI ${ }^{3}$ \\ ${ }^{1}$ Centro de Ciências Agrárias, Ambientais e Biológicas, Laboratório de Entomologia, \\ Universidade Federal do Recôncavo Baiano, 44380-000 Cruz das Almas, BA, Brasil \\ ${ }^{2}$ Departamento de Entomologia, Fitopatologia e Zoologia Agrícola, ESALQ/USP, \\ Av. Pádua Dias, 11, 13418-900 Piracicaba, SP, Brasil \\ ${ }^{3}$ Instituto de Zootecnia/ APTA, SAA, Rua Heitor Penteado, 56, 13460-000 Nova Odessa, SP, Brasil \\ Manuscript received on November 11, 2006; accepted for publication on June 6, 2007; \\ presented by LUCIA MENDONÇA PREVIATO
}

\begin{abstract}
Knowledge about the botanical source of honey is very important for the beekeeper while it indicates adequate and abundant supply sources of nectar and pollen for the bees, thus contributing toward improved yield. The present study means to identify the pollen types occurring in 58 samples of honey produced in two states of the northeastern region of Brazil, Piauí (38 samples) and Ceará (20 samples), and to verify the potential of the honey plants during the months of February to August. The samples were obtained directly from beekeepers in each state and analyzed at the Apiculture Laboratory of the Entomology Section of Escola Superior de Agricultura “Luiz de Queiroz", USP, Piracicaba, State of São Paulo, Brazil. The pollen analysis was performed using the acetolysis method. The samples were submitted to both a qualitative and a quantitative analysis. The dominant pollen in the State of Ceará is from Mimosa caesalpiniaefolia, M. verrucosa, Borreria verticillata, Serjania sp., and a Fabaceae pollen type, while in the State of Piauí it is from Piptadenia sp., M. caesalpiniaefolia, M. verrucosa, Croton urucurana and Tibouchina sp.
\end{abstract}

Key words: pollen type, honey, Apis mellifera, bee plant, Ceará, Piauí.

\section{INTRODUCTION}

The identification of plants used by honeybees assumes great importance, since it provides beekeepers with indications about adequate and abundant nectar and pollen supply sources (Howes 1953), especially considering that beekeeping in Brazil is targeted at an improved use of the richness offered spontaneously by the natural vegetation.

Knowledge about the pollen morphology of honey plants is important in the identification of plant species which contribute toward composition of honey. Preserving and multiplying those plants is also necessary,

Correspondence to: Luís Carlos Marchini

E-mail: lcmarchi@esalq.usp.br aiding in the establishment of a sustainable apiculture (M.C. Santos Júnior and F.A.R. Santos, personal communication). The pollen involuntarily collected by bees at nectar collection time is an important indicator of its botanical and especially geographical origin (Barth 1989, E.M.A.F. Bastos, personal communication).

The qualitative and quantitative palynological survey of a honey sample constitutes its pollen spectrum. This spectrum relates to nectar-producing plants, nonnectar-producing plants, contaminations, tainted honey, and mixtures (Barth 1989). Pollen qualitative analysis can provide important data, especially for honey characterization with reference to its geographic origin, occurrence of nectariferous plants, collection season, and at a later time with regard to honey determination from 
an unknown or questionable origin (Barth 1989). By means of quantitative pollen grain analysis, the honey makeup can be established, and the nectariferous botanical species which gave origin to it can be determined (Iwama and Melhem 1979). Studies developed by Santos (1963, 1978), Barth (1969, 1970 a,b,c, 1971a, 1989, 1990, 2004), Cortopassi-Laurino and Gelli (1991), B.M. Freitas (personal communication), Aires and Freitas (2001), Sodré et al. (2001), Arruda et al. (2005), and Persano-Oddo et al. (2004) demonstrated the importance of pollen found in honeys in furnishing knowledge about the botanical and geographic origin of the resource-providing plants, thus increasing the use of these trophic resources.

The present study means to identify the pollen types occurring in 58 samples of honey produced in two states of the northeastern region of Brazil, Piauí (38 samples) and Ceará (20 samples), and to verify the potential of honey plants during certain seasons of the year.

\section{MATERIALS AND METHODS}

Fifty-eight samples of honey produced by Apis mellifera L., 1758 (Hymenoptera: Apidae) were collected in the period from February to August 2002, directly from beekeepers at different cities in the states of Ceará (Araripe sample number 1; Santana do Cariri sample number 2; Asoré sample number 3; Iguatu sample numbers 4, 5, 6, 9, 14, 15, 16, and 17; Crato sample numbers 7, 10, 11, and 12; Missão Velha sample numbers 8 and 13; Pracajús sample numbers 18, 19, and 20), and Piauí (Pimenteiras sample numbers 21 and 22; Picos samples numbers 23, $24,25,26,27,28,30,31,32,33,34,35,36,37,38$, $39,40,41,42,43,44,45,46,47,48,49,50,51,52$, $53,54,55,56,57$, and 58; Socorro sample number 29). The pollen analyses of honey were performed at the Useful Insects Laboratory of Departamento de Entomologia, Fitopatologia e Zoologia Agrícola of Escola Superior de Agricultura “Luiz de Queiroz”, Piracicaba Campus, Universidade de São Paulo.

All honey samples were prepared using the acetolysis method (Erdtman 1952) and then submitted to both a qualitative and a quantitative analysis.

\section{QUALITATIVE ANALYSIS}

The qualitative analysis, referring to the pollen types present in the samples, was determined by comparison with a reference slide collection (600 species) and the descriptions of pollen grains obtained from the specialized literature (Barth 1970 a,b,c, 1971a,b, 1989, 1990).

\section{QUANTITATIVE ANALYSIS}

The quantitative analysis was performed by consecutively counting 300 pollen grains/replicate/sample. Percentages and classes of occurrence were determined. According to Louveaux et al. (1978) these are the dominant pollen ( $>45 \%$ of total grains) $(\mathrm{Dp})$, accessory pollen (16 to $45 \%$ ) (Ap), important isolated pollen (3 to 15\%) (Iip), and occasional isolated pollen $(<3 \%)$ (Oip). The results presented here correspond to the average of two counts.

For some plant species, the term "pollen type" was assigned, due to the little knowledge available about the honey species in the study region. We resorted to pollen type, which comprises all species that have equal or similar pollen grains, either belonging or not to a species in the same genus (Barth 1970b).

\section{RESULTS AND DISCUSSION}

The pollen analysis results are shown in Tables I and II and Figures 1 and 2.

Figures 1 and 2 allow the visualization of the dominant pollen types occurring in honey samples from the states of Ceará and Piauí analyzed.

The qualitative pollen analysis of the 58 honey samples showed a great variety of pollen grain types. Fortyone pollen types were found, distributed through 17 botanical families in the State of Ceará, while 39 pollen types, distributed through 19 botanical families, were found in the State of Piauí (Tables I and II). This information may contribute toward the characterization of honeys from these states with regard to their botanical origin.

The quantitative pollen analysis detected five different pollen types occurring as dominant pollen in the 20 samples of the State of Ceará that were analyzed: $M i$ mosa caesalpiniaefolia (Mimosaceae) (50.0\%), M. verrucosa (Mimosaceae) (5.0\%), Borreria verticillata $(\mathrm{Ru}-$ biaceae) (10.0\%), Serjania sp. (Sapindaceae) (5.0\%), and Fabaceae type (Fabaceae) (5.0\%) (Table I). Five 


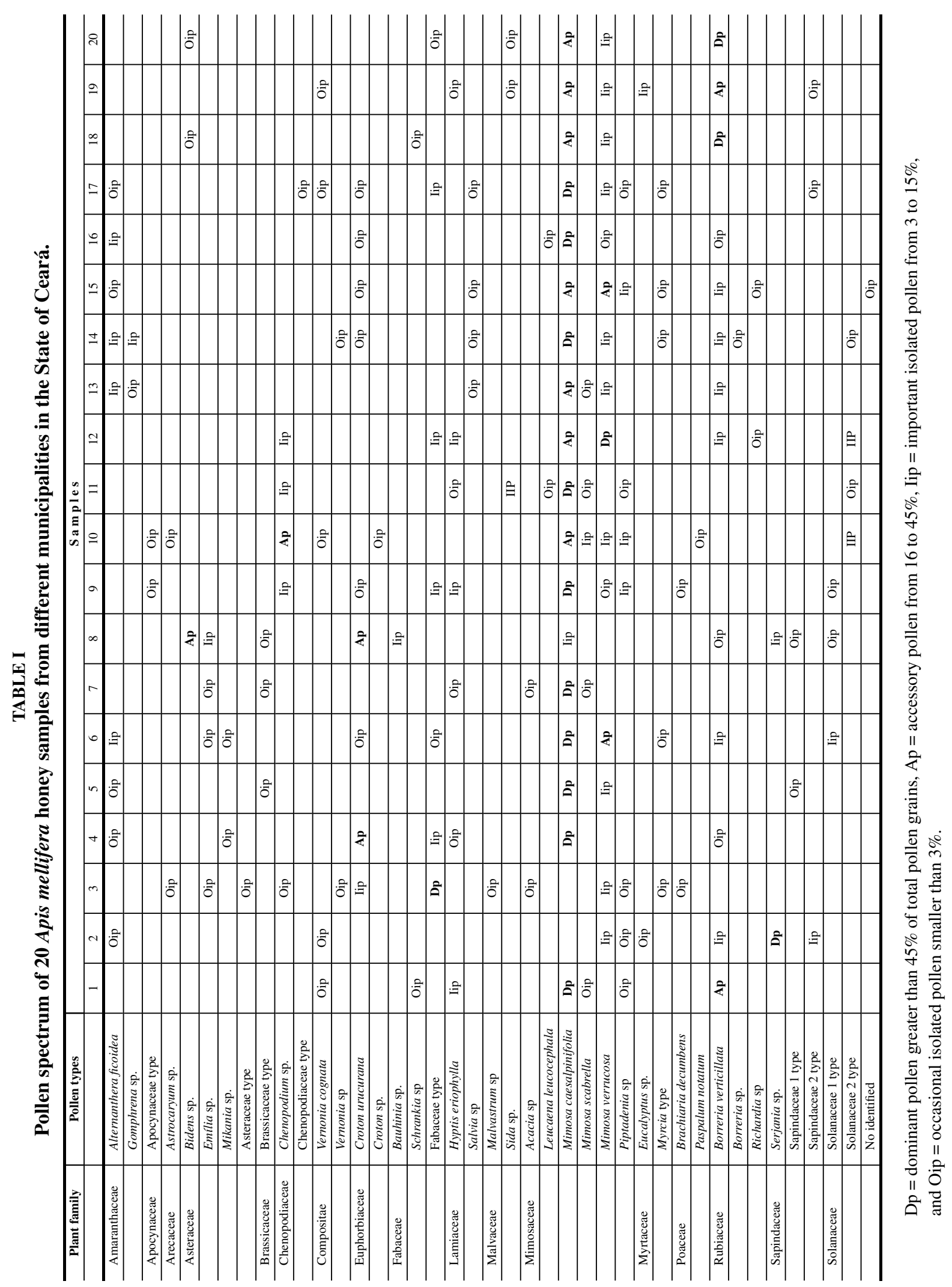




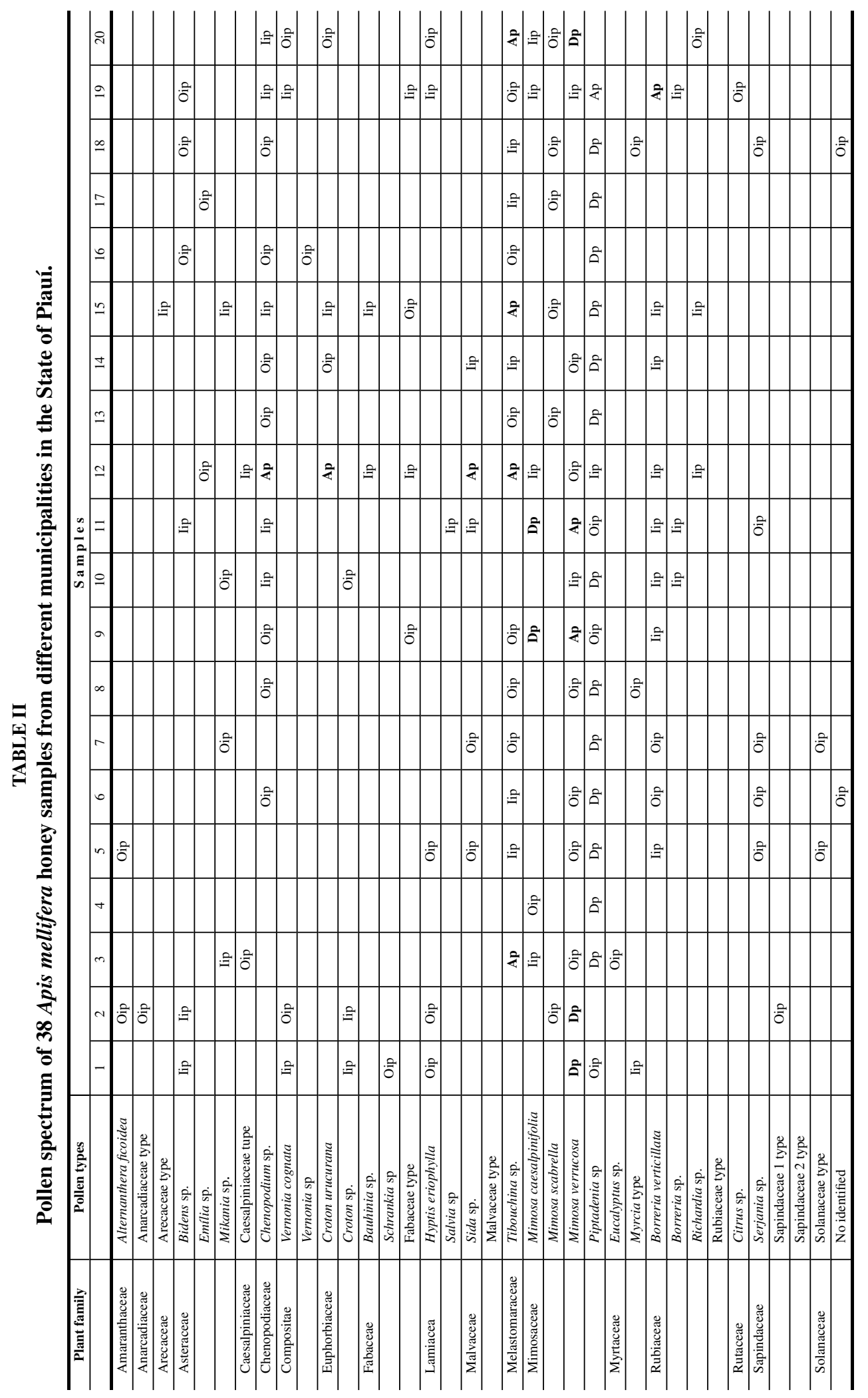




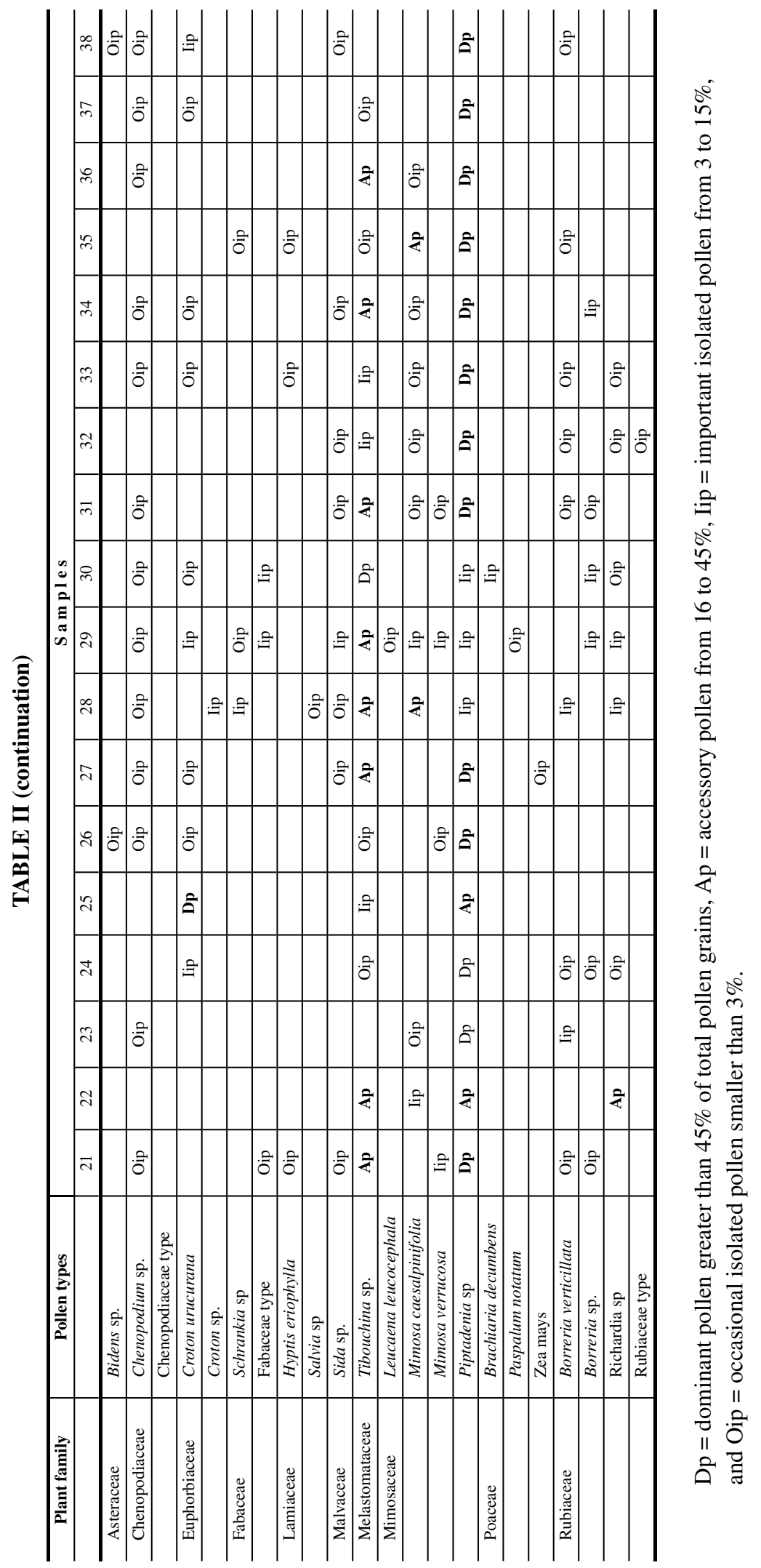



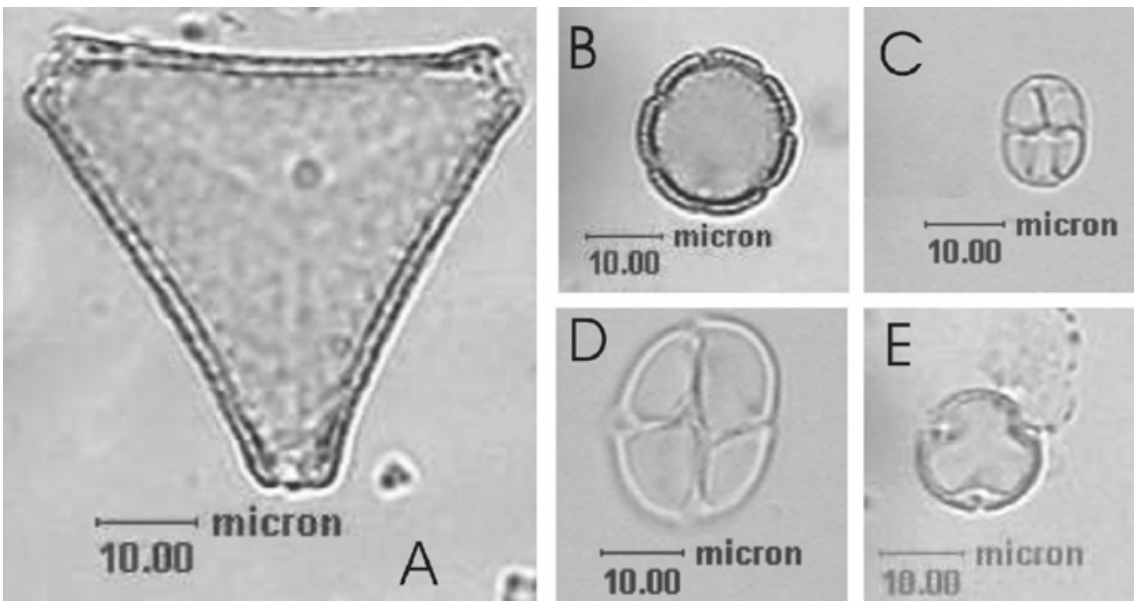

Fig. 1 - Dominant pollen types found in 20 Apis mellifera honey samples from the State of Ceará. A - Serjania sp. (Sapindaceae); B - Borreria verticillata (Rubiaceae); C - Mimosa caesalpiniaefolia (Mimosaceae); D - M verrucosa (Mimosaceae); E - Fabaceae Type (Fabaceae).
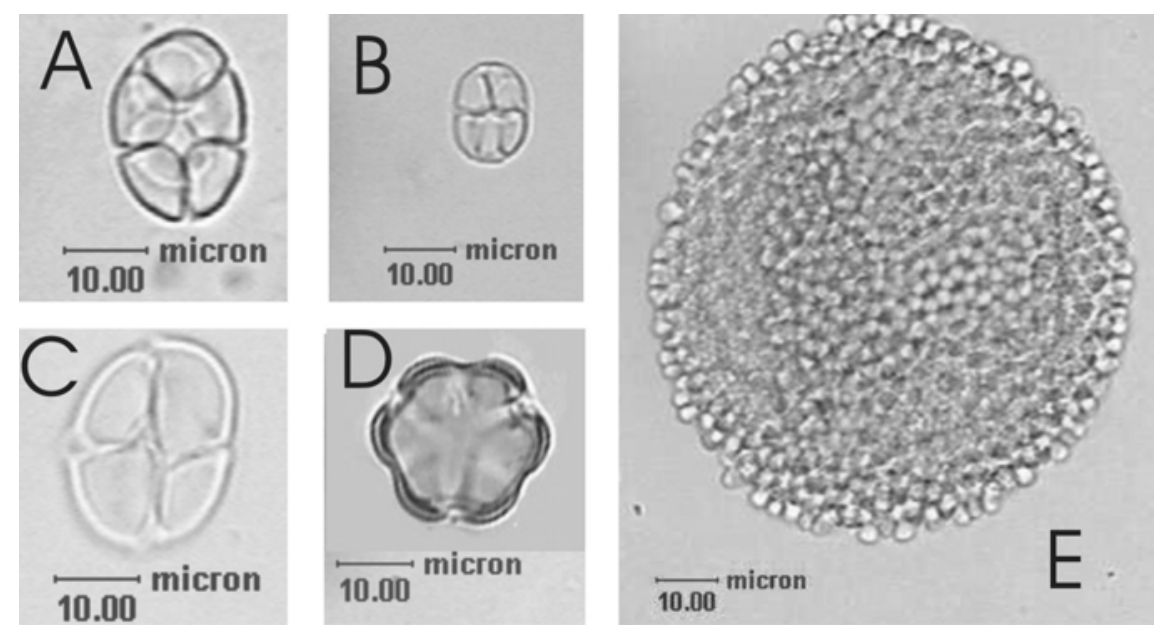

Fig. 2 - Dominant pollen types found in 38 Apis mellifera honey samples from the State of Piauí. A - Piptadenia sp. (Mimosaceae); B - M. caesalpiniaefolia (Mimosaceae); C-Mimosa verrucosa (Mimosaceae); D - Tibouchina sp. (Melastomataceae); E - Croton urucurana (Euphorbiaceae).

different pollen types were also identified as dominant pollen in the 38 samples of the State of Piauí: Piptadenia sp. (Mimosaceae) (68.4\%), M. caesalpiniaefolia (Mimosaceae) (5.3\%), M. verrucosa (Mimosaceae) (7.9\%),

\section{Croton}

urucurana (Euphorbiaceae) (2.6\%), and Tibouchina sp. (Melastomataceae) (2.6\%) (Table II).

It can be seen that the samples in both states are quite similar with regard to their floral origins, as they were collected in the same season and at nearby geographic regions. The quantitative pollen analysis of the honeys demonstrated the important participation of $M$. caesalpiniaefolia in the makeup of honeys from the State of Ceará. In the State of Piauí, in addition, the strong participation of the genus Piptadenia sp. was detected. These two pollen types reiterate the beekeeping potential of these plants in the states under study.

Barth (1989) mentioned that the pollen from Mi- 
mosaceae plants like $M$. caesalpiniaefolia, M. verrucosa, and M. scabrella types were frequently found in honey from the states of Ceará and Bahia, and that these pollen types cannot be used to discriminate between honeys produced in each state. In addition, pollen grains from the Borreria verticillata and B. latifolia types, found at high percentages in some samples, could indicate that a honey came from the State of Ceará. In the present work, the high frequency of the M. caesalpiniaefolia pollen type was observed in samples from the State of Ceará; this species was found in 10 samples as dominant pollen, followed by Borreria verticillata in two samples only. B.M. Freitas (personal communication) had previously verified the importance of $M$. caesalpiniaefolia as a honey plant in the State of Ceará, and this was later confirmed by Noronha (personal communication).

Aires and Freitas (2001), however, verified the occurrence of Cocos nucifera, Alternanthera tenella, and Eucalyptus sp. in monofloral honeys, and the predominance of family Mimosaceae in heterofloral honeys from the State of Ceará Arruda et al. (2005) analyzed honey samples from Chapada do Araripe, Ceará, and verified Serjania sp. and the Cordia pollen type as dominant during the months of November and December.

Honey samples showing a predominance of the Piptadenia moniliformis pollen type, indicate that the honey is from the State of Piauí (Barth 1989). In our work, 26 samples (68.4\% of all samples from Piauí) showed this genus as the dominant pollen.

Based upon the quantitative analysis of pollen grains, we were able to observe a great participation of accessory pollen in the samples, corresponding to $55.0 \%$ of the samples for the State of Ceará and 58\% of the samples for Piauí. Barth (1970b) mentioned that honeys containing accessory pollen occur frequently, due to the fact that Brazilian beekeeping is carried out in a primitive manner with regard to bee pasture. The author highlighted the importance of accessory and dominant pollen with reference to the amount of nectar supplied. In the present work, we observed samples containing accessory pollen without the presence of dominant pollen for the State of Ceará in samples 8, 10, 13, 15, and 19 (25.0\% of samples) (Table I), and for the State of Piauí in samples 11, 12, 19, 22, 28, and 29 (15.8\%) (Table II).
The following plant species were observed as accessory pollen types: Bidens sp., Chenopodium sp., $C$. urucurana, M. caesalpiniaefolia, $M$. verrucosa, and $B$. verticillata for the State of Ceará, and Chenopodium sp., C. urucurana, Sida sp., Tibouchina sp., M. caesalpiniaefolia, M. verrucosa, Piptadenia sp., B. verticillata, and Richardia sp. for the State of Piauí.

According to A.F. Silva et al. (personal communication) the most important plants visited in the State of Piauí for the production of honey are "marmeleiro" (Croton sonderianus), "jitirana" (Hyptis suaveolens), "camaratiba" (Cratylia mollis), "silvestre" (Serjania glabrata), and "angico de bezerro" (Piptadenia molinis). In the present work, two genera were verified to fall into the dominant or accessory pollen percentage range: Piptadenia (29 samples), and Croton (2 samples). The presence of Hyptis and Serjania (Table II) was also verified in the isolated pollen category, indicating the existence of these plants in the area under study.

With regard to important or occasional isolated pollen, their presence was observed in almost all samples studied (Tables I and II). This pollen type has little importance with regard to the amount of nectar supplied; however, it provides information with regard to the source and geographic origin of the sample (Barth 1989).

\section{CONCLUSIONS}

Typical honeys from the State of Ceará contain mostly M. caesalpiniaefolia as dominant pollen; in turn, honeys from the State of Piauí contain Piptadenia sp., demonstrating the importance of these plants in those states during the months of February through August.

Species like M. verrucosa, M. scabrella, Serjania sp., C. urucurana, and two species in the genus Borreria were observed in both states studied and have potential as honey plants during certain seasons of the year.

\section{RESUMO}

O conhecimento da origem botânica do mel é de grande importância para o apicultor por indicar fontes adequadas e de abundante suprimento de néctar e pólen para as abelhas, contribuindo, desta forma, para uma melhor produção. O presente estudo teve como objetivo identificar os tipos polínicos em 58 amostras de méis produzidos em dois estados da região 
nordeste do Brasil, Piauí (38 amostras) e Ceará (20 amostras), verificando o potencial das plantas apícolas durante os meses de fevereiro a agosto. As amostras foram obtidas diretamente de apicultores de cada Estado e analisadas no Laboratório de Apicultura do Setor de Entomologia da Escola Superior de Agricultura "Luiz de Queiroz", USP, Piracicaba, Estado de São Paulo. A análise polínica foi realizada utilizando-se o método da acetólise. As amostras foram submetidas às análises qualitativa e quantitativa. Constatou-se como pólen dominante no Estado do Ceará, Mimosa caesalpiniaefolia, M. verrucosa, Borreria verticillata, Serjania sp. e tipo polínico Fabaceae e para o Estado do Piauí, Piptadenia sp., M. caesalpiniaefolia, M. verrucosa, Croton urucurana e Tibouchina sp.

Palavras-chave: Tipo polínico, mel, Apis mellifera, planta apícola, Ceará, Piauí.

\section{REFERENCES}

AIRES ERB AND FreitAS BM. 2001. Caracterização palinológica de algumas amostras de mel do Ceará. Cienc Agron 32: 22-29.

ARruda CMF de, Marchini LC, Moreti AC DE CC, OTSUK IP AND SODRÉ G DA S. 2005. Características físico-químicas de méis da Chapada do Araripe/ Santana do Cariri-Ceará. Acta Sci Animal Sciences 27: 171-176.

BARTH OM. 1969. Pollen spektrum einiger brasilianischer Honige. Z Bienenforsch 9: 410-419.

BARTh OM. 1970a. Análise microscópica de algumas amostras de mel. 1. Pólen Dominante. An Acad Bras Cienc 42: $351-366$.

BARTH OM. 1970b. Análise microscópica de algumas amostras de mel. 2. Pólen Acessório. An Acad Bras Cienc 42: 571-590.

BARTH OM. 1970c. Análise microscópica de algumas amostras de mel. 3. Pólen Isolado. An Acad Bras Cienc 42: $747-772$

BARTH OM. 1971a. Análise microscópica de algumas amostras de mel. 6. Espectro polínico de algumas amostras de mel dos Estados da Bahia e do Ceará. Rev Bras Biol 31: 431-434.
BARTH OM. 1971b. Mikroskopische Bestandteile brasilianischer Honigtauhonige. Apidologie 2: 157-167.

BARTH OM. 1989. O pólen no mel brasileiro. Rio de Janeiro, RJ, Brasil, Gráfica Luxor, 152 p.

BARTH OM. 1990. Pollen in monofloral honeys from Brazil. J Apic Res 29: 89-94.

BARTH OM. 2004. Melissopalynology in Brazil: a review of pollen analysis of honeys, propolis and pollen loads of bees. Sci Agric 61: 342-350.

Cortopassi-Laurino M AND Gelli DS. 1991. Analyse pollinique, propriétés physico-chimiques et action antibactérienne des miels d'abeilles africanisées Apis mellifera et de Méliponinés du Brésil. Apidologie 22: 61-73.

ERdTMAn G. 1952. Pollen morphology and plant taxonomy - Angiosperms. Stockholm: Almqvist and Wiksell, 539 p.

Howes FN. 1953. Plantas melíferas. Barcelona, Espanha, Reverté, 35 p.

IWAma S AND MELhem TS. 1979. The pollen spectrum of the honey of Tetragonisca angustula angustula Latrelle (Apidae, Meliponinae). Apidologie 10: 275-295.

Louveaux J, Maurizio A And Vorwohl G. 1978. Methods of Melissopalinology. Bee World 59: 139-157.

Marchini LC, Moreti AC DE CC, Teixeira EW, Silva ECA, Rodrigues RR AND Souza VC. 2001. Plantas visitadas por abelhas Africanizadas em duas localidades do Estado de São Paulo. Sci Agric 58: 413-420.

Persano-Oddo L et al. 2004. Botanical species giving unifloral honey in Europe. Apidologie 35: 82-93.

SANTOS CFO. 1963. Características morfológicas dos grãos de pólen das principais plantas apícolas. An ESALQ 20: 175-228.

SANTOS CFO. 1978. Morfologia do pólen de algumas compostas apícolas. An ESALQ 35: 441-456.

Sodré G DA S, MARChinI LC, MORETI AC DE CC AND CARVAlho CAL DE. 2001. Análises polínicas de méis de Apis mellifera L., 1758 (Hymenoptera: Apidae) do litoral norte do Estado da Bahia. Rev Agric 76: 215-225. 